\title{
Celery Breeding Program at the Department of Vegetable Crops, University of California, Davis
}

Celery (Apium graveolens L.) is an important vegetable in California and is grown mostly in the coastal areas of Ventura, Monterey, San Luis Obispo, and Santa Barbara counties. According to 1989 statistics, 8900 ha of celery, valued at about $\$ 164$ million, was harvested that year. California produces $50 \%$ to $60 \%$ of the total celery grown in the United States-enough to supply its own demand and export the remainder to other parts of the country. Recognizing the high value and importance of this crop, California growers established the California Celery Research Advisory Board in Oct. 1976 to promote celery research. The board has supported our research program since its initiation.

Apium graveolens is used not only for its stalks, but also for its seeds, leaves, and roots. Variety dulce commonly is cultivated in the United States for its leaf stalks. The leaves of secalinum (smallage) are used as a garnish, flavoring, or medicine, and rapaceum (celeriac) is used for its enlarged root/hypocotyl and is grown predominantly in Europe.

The Dept. of Vegetable Crops, Univ. of California (UC), Davis, is one of the few institutions in the United States and abroad currently conducting research in celery breeding and genetics. Our leading role in this area of research matches the California celery industry's leadership as the world's main celery producer. The main objective of our program at UC Davis is to develop disease- and pest-resistant lines that include resistance to fusarium yellows, late blight, or leafminers. To create an effective celery breeding program capable of handling the present and future needs of the California industry, our main priorities have been to gather a comprehensive germplasm collection and to develop the genetic infrastructure of this crop. At UC Davis, we have assembled an Apium germplasm working collection of $\approx 300$ accessions. These include commercial varieties and land races of all cultivated types, as well as a few wild species. Although there are at least 15 species in the genus, few are represented in germplasm banks throughout the world. There-

Received for publication 24 Feb. 1992. Accepted for publication 27 Mar. 1992. The cost of publishing this paper was defrayed in part by the payment of page charges. Under postal regulations, this paper therefore must be hereby marked advertisement solely to indicate this fact.

Front cover: UC26- 1 and UC 10-1 celery plants. Photographs by Donald C. Edwards, principal photographer, Dept. of Pomology, Univ. of California, Davis. fore, little is known about their potential in celery breeding.

Our program at UC Davis emphasizes the following two areas.

\section{Breeding for disease and pest resistance}

Fusarium yellows is a vascular disease caused by the pathogen Fusarium oxysporum Schlecht f.s. apii (R. Nelson \& Sherb.) Snyd. $\&$ Hans., race 2, and results when the fungus penetrates the roots and invades the plant's vascular tissue. Plants infected with the fungus become yellow and stunted due to crown and root rot, and eventually die. There is no practical means of controlling the disease, which currently is spreading in the celery fields of California and other states. New stands of celery cannot be grown in infected fields.

Developing fusarium-resistant varieties is a feasible solution to this problem. For this purpose, Thomas Orton, using celeriac accessions resistant to fusarium yellows, founded a celery breeding and genetics program at UC

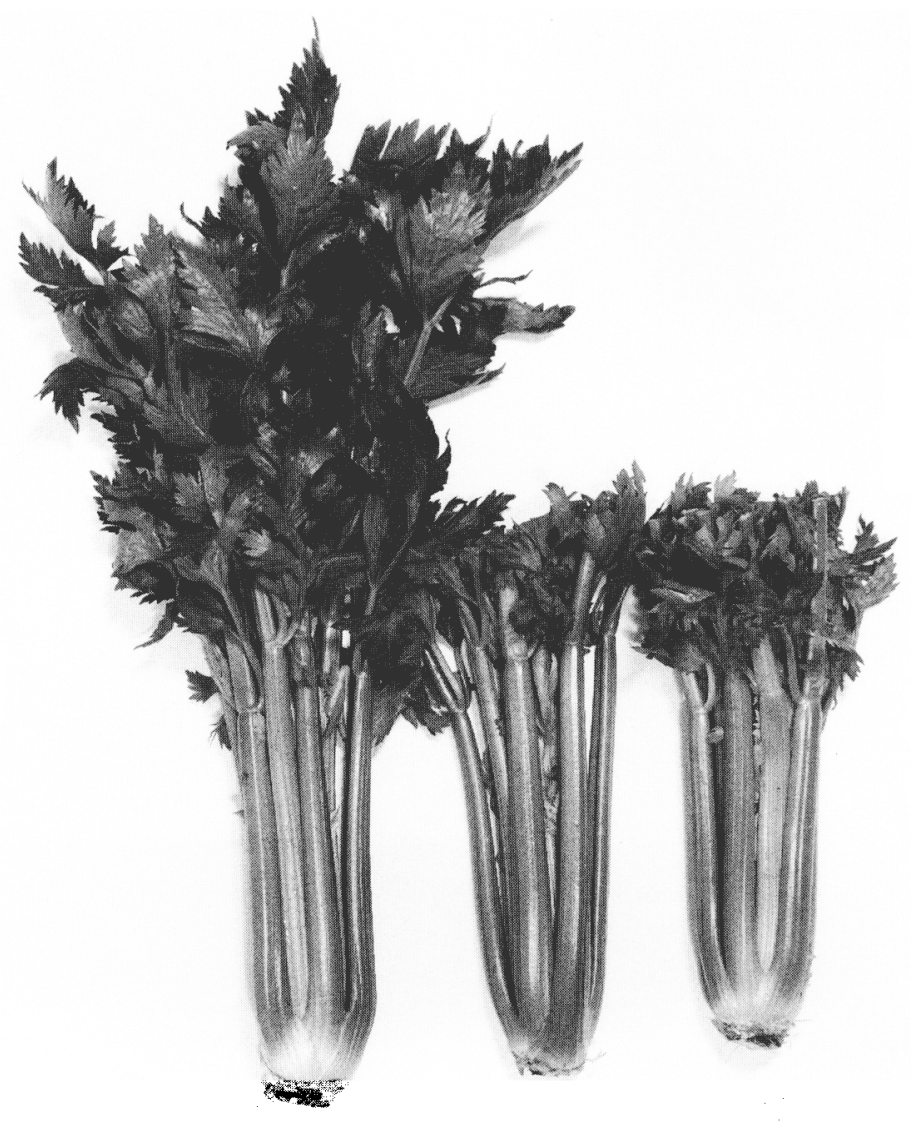

Fig. 1. Trimmed and untrimmed plants of line UC8- 1.
Davis in 1977. I took over the program in 1983 and produced the first fusarium-resistant line, UC1, in 1984 (Orton et al., 1984). Celeriac P1169001, a land race from Turkey, was the main source for resistance used in developing UC1. Although plants of this accession are not immune, they have a high level of resistance, with $25 \%$ of the plants displaying slight symptoms of fungal penetration in heavily infested fields. UC1 has served as foundation material for further selection and release of the first commercial fusarium-resistant varieties developed by the seed industry.

To improve UC1 for horticultural traits, we have implemented a backcross program to introgress resistance to three popular celery varieties, 'Tall Utah 52-70R', 'T.U. 52-70HK', and 'T.U. 52-75'. As a product of this program, we have released the next generation of fusarium-resistant lines, UC8-1, UC 10-1, and UC26-1, which are described on p. 351. Our goal is to advance this material further for additional releases in the future. Typical trimmed and untrimmed plants of these lines are depicted on the front cover (UC26-1 and UC10-1) and in Fig. 1 (UC8-1).

Late blight, caused by the pathogen Septoria apicola Speg., is another important disease affecting celery. Although there are means to control late blight, developing resistant varieties will reduce production costs and fungicide applications. Although our search for resis

(continued on p. 359) 
(continuedfrom inside front cover)

tance in cultivated accessions was unsuccessful, we found resistance in the wild species A. chilense Zoll. and A. nodiflorum (L.) Lag. (Ochoa and Quiros, 1989). Apium chilense hybridized readily to celery, but the $F_{1}$ hybrids had poor fertility due to the presence of chromosomal rearrangements. Although it was not possible to obtain F, seed, backcross seed was obtained, and we are trying to produce lateblight-resistant lines from this material.

Leafminer (Lyrimiza trifolii Burgess) is a major pest of celery and currently is being controlled by routine insecticide spraying. Developing leafminer-resistant celery varieties will reduce hazardous chemical use and environmental risks linked to their use. No resistance to this pest was observed in the cultivated collection; however, we found an accession of A. prostratum Vent. from Australia to be practically immune in no-choice greenhouse tests. No feeding or oviposition was observed in this species (Trumble and Quiros, 1988). We have hybridized A. prostratum to celery and derived $\mathrm{BC}_{1}$ progeny in an attempt to develop leafminer-resistant lines. Chemical analysis of the foliage is being done in conduction with the breeding program to ensure the resistance is not based on noxious compounds (Trumble et al., 1990).

\section{Literature Cited}

Developing the genetics of this crop will expedite breeding. We are creating chromosome markers and a genetic map based on isozymes, nonspecific proteins, morphological traits (Quiros et al., 1987), and DNA-based markers. The latter includes restriction fragment length polymorphism and amplified DNA sequences by the polymerase chain reaction. Through the genetic map, we can tag useful genes, such as those determining fusarium resistance and male sterility. We are also interested in using male sterility to develop disease-resistant F, hybrids (Quiros et al., 1986). Male-sterile plants were found in P1229526, a land race from Iran.

Finally, another research component is to adapt new genetic engineering techniques that would be useful to breeders. This includes developing transformation procedures for gene transfer. We accomplished this task using Agrobacterium tumefaciens as a vector (Catlin et al., 1988).

In summary, we are confident that the celery genetics program at UC Davis, with its broad germplasm base and comprehensive genetic information, will serve to adapt and solve present and future problems faced by celery growers.
Catlin, D., O. Ochoa, S. McCormick, and C.F. Quiros. 1988. Celery transformation by Agrofracterium tumefaciens: Cytological and genetical analysis of transformed plants. Plant Cell Rpts. 7:100-103.

Oehoa, O. and C.F. Quiros. 1989. Apium wild species: Novel sources for resistance to late blight in celery. Plant Breeding 102:3 17-321.

Orton, T.J., S.H. Hulbert, M.E. Durgan, and C.F. Quiros. 1984. UCI, fusarium yellows-resistant celery breeding line. HortScience 19:594.

Quiros, C. F., A. Rugama, Y.Y. Dong, and T.J. Orton. 1986. Cytological and genetical studies of a male sterile celery. Euphytica 35:867-875.

Quiros, C. F., J.M. McGrath, and J.L. Stites. 1987. Use of stem proteins and isozymes for the identification of celery varieties. Plant Cell Rpts. 6:114117.

Trumble, J.T. and C.F. Quiros. 1988. Antixenotic and antibiotic resistance in Apium species to Liyomiza trifolii (Burgess). J. Econ. Entomol. 81:602-607.

Tremble, J.T., W. Derks, C.F. Quiros, and R.C. Beier. 1990. Host plant resistance and linear furanocoumarin content in Apium species, J. Econ. Entomol. 83:519-525.

Carlos F. Quiros Dept. of Vegetable Crops Univ. of California Davis, CA 95616 